\title{
Growth, stoichiometry and cell size; temperature and nutrient responses in haptophytes
}

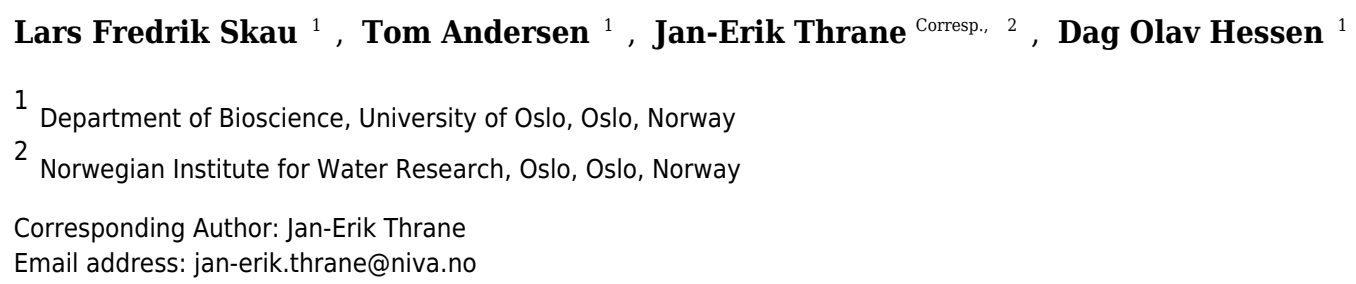

Temperature and nutrients are key factors affecting the growth, cell size, and physiology of marine phytoplankton. In the ocean, temperature and nutrient availability often co-vary because temperature drives vertical stratification, which further controls nutrient upwelling. This makes it difficult to disentangle the effects of temperature and nutrients on phytoplankton purely from observational studies. In this study, we carried out a factorial experiment crossing two temperatures $\left(13^{\circ}\right.$ and $\left.19^{\circ} \mathrm{C}\right)$ with two growth regimes (P-limited, semi-continuous batch cultures ["-P"] and nutrient replete batch cultures in turbidostat mode $\left.\left["+P^{\prime \prime}\right]\right)$ for three species of common marine haptophytes (Emiliania huxleyi, Chrysochromulina rotalis and Prymnesium polylepis) to address the effects of temperature and nutrient limitation on elemental content and stoichiometry ( $\mathrm{C}: \mathrm{N}: \mathrm{P})$, total RNA, cell size, and growth rate. We found that the main gradient in elemental content and RNA largely was related to nutrient regime and the resulting differences in growth rate and degree of P-limitation, and observed reduced cell volume-specific content of P and RNA (but also N and $C$ in most cases) and higher $\mathrm{N}: \mathrm{P}$ and $\mathrm{C}: \mathrm{P}$ in the slow growing $-\mathrm{P}$ cultures compared to the fast growing $+\mathrm{P}$ cultures. P-limited cells also tended to be larger than nutrient replete cells. Contrary to other recent studies, we found lower N:P and C:P ratios at high temperature. Overall, elemental content and RNA increased with temperature, especially in the nutrient replete cultures. Notably, however, temperature had a weaker - and in some cases a negative - effect on elemental content and RNA under P-limitation. This interaction indicates that the effect of temperature on cellular composition may differ between nutrient replete and nutrient limited conditions, where cellular uptake and storage of excess nutrients may overshadow changes in resource allocation among the non-storage fractions of biomass (e.g. P-rich ribosomes and N-rich proteins). Cell size decreased at high temperature, which is in accordance with general observations. 
1 Growth, stoichiometry and cell size; temperature and nutrient responses in haptophytes.

2 Lars Fredrik Skau ${ }^{1}$, Tom Andersen ${ }^{1}$, Jan-Erik Thrane ${ }^{2}$, Dag Olav Hessen ${ }^{1}$

3

$4 \quad{ }^{1}$ Department of Biosciences, University of Oslo, Oslo, Norway

$5 \quad{ }^{2}$ Norwegian Institute for Water Research, Oslo, Norway

6

7

8 Corresponding author: Jan-Erik Thrane

9 E-mail: jan-erik.thrane@niva.no

10

11

12

13

14

15

16

17

18

19

20

21

22

23

24

25

26

27

28

29

30

31 Abstract 
32

33 Temperature and nutrients are key factors affecting the growth, cell size, and physiology of

34 marine phytoplankton. In the ocean, temperature and nutrient availability often co-vary because

35 temperature drives vertical stratification, which further controls nutrient upwelling. This makes it

36 difficult to disentangle the effects of temperature and nutrients on phytoplankton purely from

37 observational studies. In this study, we carried out a factorial experiment crossing two

38 temperatures $\left(13^{\circ}\right.$ and $\left.19^{\circ} \mathrm{C}\right)$ with two growth regimes (P-limited, semi-continuous batch

39 cultures ["-P"] and nutrient replete batch cultures in turbidostat mode ["+P"]) for three species

40 of common marine haptophytes (Emiliania huxleyi, Chrysochromulina rotalis and Prymnesium

41 polylepis) to address the effects of temperature and nutrient limitation on elemental content and

42 stoichiometry $(\mathrm{C}: \mathrm{N}: \mathrm{P})$, total RNA, cell size, and growth rate. We found that the main gradient in

43 elemental content and RNA largely was related to nutrient regime and the resulting differences in

44 growth rate and degree of $\mathrm{P}$-limitation, and observed reduced cell volume-specific content of $\mathrm{P}$

45 and RNA (but also $\mathrm{N}$ and $\mathrm{C}$ in most cases) and higher $\mathrm{N}: \mathrm{P}$ and $\mathrm{C}: \mathrm{P}$ in the slow growing -P

46 cultures compared to the fast growing +P cultures. P-limited cells also tended to be larger than

47 nutrient replete cells. Contrary to other recent studies, we found lower N:P and C:P ratios at high

48 temperature. Overall, elemental content and RNA increased with temperature, especially in the

49 nutrient replete cultures. Notably, however, temperature had a weaker - and in some cases a

50 negative - effect on elemental content and RNA under P-limitation. This interaction indicates

51 that the effect of temperature on cellular composition may differ between nutrient replete and

52 nutrient limited conditions, where cellular uptake and storage of excess nutrients may

53 overshadow changes in resource allocation among the non-storage fractions of biomass (e.g. P-

54 rich ribosomes and N-rich proteins). Cell size decreased at high temperature, which is in

55 accordance with general observations.

56

57 


\section{Introduction}

60 Marine phytoplankton constitute nearly $50 \%$ of the global primary productivity (Field et al.

61 1998) and are an essential component in the biogeochemical cycling of carbon (C), nitrogen (N),

62 and phosphorus (P) (Arrigo 2005). Increased temperatures in the ocean due to climate change

63 will influence phytoplankton both directly through temperature dependent physiological

64 processes, but also indirectly through increased water column stability. The latter will likely limit

65 nutrient supply and reduce productivity in stratified tropical waters, but may increase

66 productivity at higher latitudes, where phytoplankton growth is constrained by light and deep

67 mixing (Behrenfeld et al. 2006, Boyce et al. 2010). Large expanses of the ocean phytoplankton

68 growth is nutrient-limited (Moore et al. 2013), hence the interaction between temperature and

69 nutrient status is of considerable ecological and biogeochemical importance. Knowledge of how

70 phytoplankton growth, stoichiometry, and size structure respond to combined changes in these

71 factors is important to predict how productivity, food web dynamics, and the biogeochemical

72 cycling of $\mathrm{C}, \mathrm{N}$ and $\mathrm{P}$ will be affected in a warmer and more stratified ocean (Arrigo et al. 1999,

73 Arrigo 2005, Litchman et al. 2015, Sommer et al. 2016).

74 Direct effects of temperature on phytoplankton are related to kinetic responses.

75 Temperature increases enzyme and ribosome activity and thereby processes like nutrient uptake

76 and translation. Ultimately, this leads to higher rates of overall processes like protein synthesis,

77 light saturated photosynthesis, and cell division when temperature is elevated towards the

78 optimum and other factors are non-limiting (Raven and Geider 1988, Davidson 1991).

79 Temperature adjustment of growth in autotrophs has also been related to elemental content and

80 stoichiometry since allocation to different macromolecular pools, and thereby the absolute and

81 relative requirements for elements like $\mathrm{N}$ and $\mathrm{P}$, may change with temperature (Shuter 1979,

82 Rhee and Gotham 1981, Sterner and Elser 2002). In some phytoplankton species (Rhee and

83 Gotham 1981), among species of higher plants (Reich and Oleksyn 2004), and in ectotherms in

84 general (Woods et al. 2003), cellular content of $\mathrm{N}$ and $\mathrm{P}$ tend to increase in organisms grown at

85 low temperature. $\mathrm{N}$ and $\mathrm{P}$ do not necessarily change in proportion along temperature gradients

86 (Reich and Oleksyn 2004, Yvon-Durocher et al. 2015), and with increasing marine temperatures

87 one prediction is that phytoplankton N:P ratios will increase globally (Toseland et al. 2013). This

88 prediction is, in part, based on a "translation compensation hypothesis", which states that

89 because specific ribosomal reaction rate increases with temperature, lower ribosomal density will 
90 be needed to maintain the same level of protein synthesis if temperature increases (Toseland et

91 al. 2013, Daines et al. 2014). Since ribosomes are rich in P and have a low N:P ratio relative to

92 the cell as a whole, lower ribosome content will increase cellular N:P (Sterner and Elser 2002).

93 Photosynthetic activity - and thereby the allocation to $\mathrm{N}$ rich photosynthetic machinery - is also

94 expected to increase with temperature, at least under nutrient replete conditions (Shuter 1979,

95 Sterner and Elser 2002). This may further tend to elevate N:P (and C:P) if temperature increases.

96 Several observational studies have revealed a positive correlation between the N:P ratio of

97 marine seston and global temperature (Martiny et al. 2013, Toseland et al. 2013, Yvon-Durocher

98 et al. 2015). Yet, these large-scale variations are likely mostly related to changes in community

99 composition (Martiny et al. 2013, Yvon-Durocher et al. 2015), with contributions from spatial

100 differences in dissolved nutrient concentrations (Galbraith and Martiny 2015), geographical

101 differences in the relative contribution of non-algal particles to seseton, and perhaps reduced use

102 of phospholipids in cell membranes in oligotropic regions (Van Mooy et al. 2009). Not much is

103 known about the contribution from plasticity or temperature acclimation within species.

104 Also, responses in cell size have been proposed as a common response to elevated

105 temperatures across phyla and taxa (Atkinson et al. 2003, Daufresne et al. 2009, Gardner et al.

106 2011, Sheridan and Bickford 2011). But since small cell size is beneficial under nutrient scarcity

107 (due to higher surface-to-volume ratio), and warming will cause both higher water temperature

108 and generally more oligotrophic conditions through increased stratification, it is difficult to

109 disentangle the drivers based on in situ studies, at least for intraspecific changes in cell size.

110 Experimental studies on phytoplankton indicate contributions both from ambient nutrient levels

111 and temperature per se to cell size (Peter and Sommer 2013), although resource availability

112 (productivity) is the dominating driver for the size structure of the community (Marañón et al.

113 2012).

114 To elucidate stoichiometric and cell size responses to temperature and nutrient limitation,

115 and the potential differences in temperature response between nutrient replete and nutrient

116 limited conditions, we conducted a factorial experiment with three common marine haptophytes

117 crossing two temperatures with two nutrient regimes. We measured the response of growth rate,

118 elemental content (C, N, and P), total RNA content, and cell size, and hypothesized that 1) high

119 temperature will decrease elemental and RNA content, 2) high temperature will increase N:P and

120 C:P ratios, 3) high temperature will reduce cell size, 4) growth rate and elemental content will 
121 increase under nutrient replete growth, and 5) the effect of temperature on especially P and RNA

122 content will differ between P-limited and nutrient replete growth. This is expected, because

123 under P-limitation P and RNA more directly reflect the non-storage requirements, and P-content

124 is not confounded by excess storage (luxury consumption), which may be significant under

125 nutrient replete conditions (Klausmeier et al. 2008).

126

\section{Material and Methods}

128 We carried out experiments with the three species Emiliania huxleyi (Lohmann) Hay \& Mohler, 129 1967; Chrysochromulina rotalis Eikrem \& Throndsen, 1999; and Prymnesium polylepis (Manton

130 \& Parke) Edvardsen, Eikrem \& Probert 2011 - all haptophytes in the class Coccolithophyceae

131 (=Prymnesiophyceae). The specific strains were initially isolated from the outer Oslo fjord

132 (Norway), and have been kept in culture at the University of Oslo for several years. We

133 cultivated the algae in IMR 1/2 medium, which is the original IMR medium with nutrient levels

134 reduced to 50\% (Eppley et al. 1967) and $10 \mathrm{nM}$ selenite added (Edvardsen and Paasche 1992).

135 We used filtered seawater $(1.2 \mu \mathrm{m}$ Whatman $\mathrm{GF} / \mathrm{C})$ and adjusted the medium to a final salinity

136 of $30 \mathrm{psu}$. Finally, we post-filtered the medium through a $0.22 \mu \mathrm{m}$ sterile filter, pasteurized it at

$13780^{\circ} \mathrm{C}$ for $15 \mathrm{~min}$, and stored it dark at $14^{\circ} \mathrm{C}$.

138 The experiment was designed as a long term, factorial setup with two P-treatments (P-

139 limited and nutrient replete; explained below) and two temperatures $\left(13^{\circ} \mathrm{C}\right.$ and $\left.19^{\circ} \mathrm{C}\right)$ in

140 triplicates for three species. This yielded 36 experimental units. Prior to the experiment, the algae

141 were cultivated in IMR $1 / 2$ medium for approximately 2 weeks at $16^{\circ} \mathrm{C}$ before being acclimated

142 to their respective temperatures for 7 days.

143 The P-limited cultures (hereafter referred to as “-P”) were grown in IMR 1/2 medium

144 reduced to $1 \mu \mathrm{M}$ phosphate, resulting in a dissolved N:P ratio of 124:1 (mol:mol). We grew the -

$145 \mathrm{P}$ cultures as batch cultures in semi-continuous mode. Every second day, a constant fraction of

146 the culture volume was removed and replaced by fresh medium. The fraction removed was $50 \%$

147 for E. huxleyi and C. rotalis, and $40 \%$ for P. polylepis. Hence, the dilution factors (DFs) were

$1481 /(1-0.5)=2$ and $1 /(1-0.4)=1.667$, respectively.

149 With the semi-continuous mode, we ensured that cell densities eventually reached a quasi

150 steady state which was limited by P due to the high N:P supply ratio (124:1). Here the state of

151 the algal cells is the same in each dilution cycle, but will change somewhat over the inter- 
152 dilution growth period due to the periodic dilution with fresh medium. The high $\mathrm{P}$ treatment 153 (hereafter referred to as “+P”) received standard IMR 1/2 with $12.5 \mu \mathrm{M}$ phosphate resulting in a

154 dissolved N:P ratio of 10:1. To make sure that we had no nutrient limitation in the $+\mathrm{P}$ cultures, 155 these were run as batch cultures in turbidostat mode, and diluted down to the same, low cell 156 density every 2-3 days; 50000 cells mL-1 for E. huxleyi and C. rotalis and 100000 cells mL $^{-1}$ for 157 P. polylepis. This ensured that the cells were P-saturated and always growing exponentially. 158 All experiments were run in $40 \mathrm{~mL}$ nunclon filtercap flasks (Thermo Scientific). The 159 cultures received an irradiance of $170 \mu \mathrm{mol}$ photons $\mathrm{m}^{-2} \mathrm{~s}^{-1}$ from fluorescent white tubes, and the 160 light: dark-cycle was set to $14 \mathrm{~h}: 10 \mathrm{~h}$. The cultures were maintained for $>20$ weeks, with regular 161 samples for determination of cell numbers and cell size. Elemental content (C, N, P), RNA and 162 alkaline phosphatase activity (APA) was measured as indices of nutrient status of the cultures. 163 Cell size (equivalent spherical diameter; ESD) was measured by a CASY electronic cell 164 counter (Scharfe system Gmbh, Rautlingen). Mean and median ESD were analyzed twice a week 165 after the cultures had stabilized. During the first weeks, cell densities were estimated from CASY 166 cell counts, but when the cultures had stabilized, we started monitoring cell densities by 167 measuring absorbance at $660 \mathrm{~nm}\left(\mathrm{~A}_{660}\right)$ using a plate reader equipped with a spectrophotometer

168 (BioTek synergy MX, Winooski, VT, USA) ). $\mathrm{A}_{660}$ was converted to cell numbers based on 169 species- and treatment-specific calibration curves constructed from parallel measurements of $170 \mathrm{~A}_{660}$ and cells numbers in the CASY $\left(\mathrm{R}^{2}>0.9\right.$ for all except one calibration curve, where $\mathrm{R}^{2}$ was $1710.75)$.

172 For the $+P$ cultures, specific growth rate was calculated as $\log \left(\mathrm{N}_{\mathrm{t}+\Delta t} / \mathrm{N}_{\mathrm{t}}\right) / \Delta \mathrm{t}$, where $\mathrm{N}_{\mathrm{t}}$ was 173 the cell density after dilution, $\mathrm{N}_{\mathrm{t}+\Delta \mathrm{t}}$ the cell density at the end of the growth interval (before the 174 next dilution), and $\Delta \mathrm{t}$ the time interval between measurements (in days). For the -P cultures, 175 growth rate was calculated as $\log \left(\mathrm{N}_{\mathrm{t}+\Delta t} /\left(\mathrm{N}_{\mathrm{t}} / \mathrm{DF}\right)\right) / \Delta \mathrm{t}$, where $\mathrm{N}_{\mathrm{t}}$ was the cell density before 176 dilution, DF the dilution factor (see above), and $\mathrm{N}_{\mathrm{t}+\Delta \mathrm{t}}$ the cell density at the end of the growth 177 interval.

178 Since the cultures (and growth rates) remained stable over time, we here report mean 179 growth rates for each species and treatment. Cultures were kept at the same light:dark cycle $180(14: 10)$, and samples were taken at the same time in the morning to ensure that cells were 181 harvested from the same cell cycle phase. 
182 Analysis of particulate C, N, and $\mathrm{P}$ was performed for all cultures at steady state. For C and

$183 \mathrm{~N}$ analysis, algae were collected on a GF/C filter and analyzed on a Thermo Finnegan EA 1112

184 series flash analyzer (Thermo Fisher scientific). Some fraction of particulate C in E. huxleyi

185 could be allocated to the calcified structures. Hence in order estimate the amount of particulate 186 organic carbon (POC) and particulate inorganic carbon (PIC), additional samples of E. huxleyi

187 were treated with $2 \mathrm{M}$ hydrochloric acid ( $\mathrm{HCl})$ to remove PIC (Langer et al. 2009). We did not

188 find significant differences in cellular $\mathrm{C}$ with or without this treatment, and we thus have based

189 the analysis on non-acidified samples as for the other two species. Particulate P was estimated by

190 filtering cells onto a GF/C filter before soaking the filter in $10 \mathrm{~mL}$ of a $1 \%$ solution of potassium

191 peroxydisulfate for 30 minutes at $120^{\circ} \mathrm{C}$, followed by colorimetric analysis in an autoanalyzer

192 (Bran Luebbe, Norderstedt Germany).

193 RNA was measured three times during steady state using a modified version of the

194 RiboGreen fluorescence protocol (Turner BioSystems). From each culture, 1-4 mL was filtered

195 onto nitrocellulose membranes (0.65 $\mu \mathrm{m}$ DAWP, Millipore), which were snap-frozen (in liquid

$196 \mathrm{~N}$ ) in nuclease-free tubes. Prior to analysis, the tubes were added $120 \mu \mathrm{L}$ of the extraction buffer

197 (1\% sarcosyl, Sigma), and while still frozen, homogenized by ice-cold sonification (Branson

198 Sonifier) for two minutes. The samples were again put on ice, and diluted 1:5 with TE buffer (10

$199 \mathrm{mM}$ Tris-HCL, $1 \mathrm{mM}$ EDTA, $\mathrm{pH}$ 7.5). Duplicates with $75 \mu \mathrm{L}$ from each sample were produced

200 in individual slots of a 96-well plate (655076 Greiner Bio-one, USA). The duplicates were

201 inserted pairwise into columns after the first column, which was reserved for an RNA standard.

202 Into each of the first duplicate columns a total of $20 \mu \mathrm{L}$ RNase-free water (Gibco BRL1071) was

203 added. The other duplicates were then added $20 \mu \mathrm{L}$ of $0.1 \%$ RNase A (A7973, Promega).

204 Immediately after the RNase mixture was added, the well plate was heat incubated at $37^{\circ} \mathrm{C}$ on a

205 shaking table to ensure homogenous dispatch of the RNase, and digestion of RNA. After the

206 incubation, $75 \mu \mathrm{L}$ of 100 times diluted RiboGreen dye (R-11490, Molecular probes, USA) was

207 added to each well with an automatic 8-channel pipette. Finally, the sample plate was inserted

208 into a plate reader (described earlier) and fluorescence of the samples measured using an

209 excitation wavelength of $480 \mathrm{~nm}$ (20 nm bandwith) and an emission wavelength of $525 \mathrm{~nm}$ (20

$210 \mathrm{~nm}$ bandwith). Since RiboGreen yields fluorescence from both RNA and DNA, we subtracted

211 the fluorescence in the RNase-treated samples from the non-RNase treated samples to obtain the

212 signal from RNA alone. Concentrations of RNA were obtained by calibrating the fluorescence of 
213 the unknown samples against the fluorescence of the known RNA standards. We converted the 214 weight of total RNA to moles of ribonucleotide monophosphates (which each contains one P215 atom) using the average molecular weight of the four different ribonucleotide monophosphates $216\left(339.5 \mathrm{~g} \mathrm{~mol}^{-1}\right)$.

217 Alkaline phosphatase activity (APA) may serve as an independent biomarker for P-

218 limitation, and was analyzed along with RNA for all treatments and species. APA was analyzed 219 by the CDP-star chemoluminescence method according to the protocol of Wojewodzic et al. 220 (2011). Samples were collected as for RNA and stored at $-80^{\circ} \mathrm{C}$ prior to analysis. For analysis, 221 samples were put on ice and $0.3 \mathrm{~mL}$ of Triton X-100 (T8787, Sigma) was added. Samples were 222 sonified as in the RNA procedure described above. The standards were then prepared by using 223 AP type VII-S from bovine intestinal mucosa (P5521, Sigma). The standard curve ranged from $2242-100 \mathrm{pU}$ of the AP, diluted with $1 \%$ Triton $\mathrm{X}-100$. One unit $(\mathrm{pU})$ is in this context the amount 225 of enzyme that is required to hydrolyze $1 \mu \mathrm{M}$ 4nitrophenyl phosphate per minute at $\mathrm{pH}=9.8$ and 226 a temperature of $37^{\circ} \mathrm{C}$. After the preparation of the standards, $20 \mu \mathrm{L}$ of both the standards and 227 the samples were transferred to a Pyrophosphate-free 96-well plate (Nunc, 236105) and 228 preserved on ice. Afterwards, $20 \mu \mathrm{L}$ of $0.4 \mathrm{mM} \mathrm{CDP}$-star was dispensed with an automatic 8229 channel pipette to all the wells, and luminescence of the samples measured in a plate reader.

Biomass normalization of $C, N, P, R N A$, and $A P A$

232 Because we observed significant differences in cell size between the experimental treatments, we 233 chose to normalize the molar amounts of C, N, P and RNA, and APA, by the total cell volume in 234 each sample. The total cell volume (in liters) in a sample was calculated as $\left[\frac{4}{3} \pi\left(\frac{\varphi}{2}\right)^{3} \eta\right] 10^{-15}$, 235 where $\eta$ is the total number of cells in the sample and $\varphi$ the median ESD (in $\mu \mathrm{m}$ ) of the cells in 236 the samples for C, N, P, RNA and APA. The factor $10^{-15}$ converts from $\mu \mathrm{m}^{3}$ to L. The resulting 237 bulk cell volume-specific concentrations have units of moles ( $\mathrm{L}$ cell volume $)^{-1}$. We will also 238 present results of cell quota, i.e., the number of moles of C, N, P, and RNA per cell.

\section{Data analysis}

241 All data analysis was done in R (R Core Team, 2016). We used principal component analysis 242 (PCA) on log-transformed and standardized cell volume-specific concentrations of C, N, P, and 243 RNA from all species to get an overview of the general trends in elemental content and RNA, 
244 and how the variables were related to P-regime, temperature, and species. To estimate the

245 fraction of variance in the dataset that was related to these three factors, we used permutational

246 multivariate ANOVA (the function adonis in the vegan package). Moreover, we tested whether

247 any of the underlying gradients in elemental content and RNA were related to growth rate and

248 the degree of P-limitation by including growth rate and APA as passive variables in the

249 ordination (using the envfit function in the vegan package; Oksanen et al. 2017). To test for

250 additive and interactive effects of P-regime and temperature on the different response variables

251 within species, we used linear models on log-transformed data. Temperature and P-regime were

252 both represented as factor variables with two levels each.

253

\section{Results}

255 The response of growth rate and APA to P-regime and temperature

256 Within the three species, 84-94 \% of the variation in specific growth rate was explained by P-

257 regime (calculated from model sums of squares), with the $+\mathrm{P}$ cultures growing significantly

258 faster than the $-\mathrm{P}$ cultures $(p<0.05$, table 1). This was expected, since we used two different

259 culturing modes (semi-continuous vs. turbidostat mode) to impose P-limited and nutrient replete

260 growth. Temperature did not influence the measured growth rate in any of the $-\mathrm{P}$ cultures $(p>$

261 0.05), which was expected since we used the same dilution rate at high and low temperature.

262 High temperature increased growth rate in the $+\mathrm{P}$ cultures of E. huxleyi and C. rotalis $(p<0.05)$.

263 In contrast, the $+\mathrm{P}$ cultures of $P$. polylepis grew slower at $19^{\circ} \mathrm{C}$ compared to $13^{\circ} \mathrm{C}(p<0.05)$.

264 APA was strongly elevated in the -P cultures for all species and temperatures, except for $C$.

265 rotalis at $13{ }^{\circ} \mathrm{C}$, where APA was similar for both P-regimes (Fig. S1 and table S1; $58 \%$ of the

266 variation in APA was explained by P-regime alone). Temperature had no significant additive

267 effect on APA $(p>0.05)$, but there was a significant interaction between temperature and species

$268(p=0.035)$ manifested by elevated APA at $19^{\circ} \mathrm{C}$ in P-limited E. huxleyi.

269

270 Overall trends in $C, N, P$, and $R N A$

271 A PCA plot of the cell volume-specific concentrations of C, N, P, and RNA from all

272 species revealed an underlying gradient from high to low concentrations along PC axis 1, which

273 explained $78.7 \%$ of the variation in the dataset (fig. 1). Cultures grown in $+\mathrm{P}$ clearly distributed

274 themselves in the left part of the PCA plot along with high cell-specific concentrations of C, N, 
$275 \mathrm{P}$, and RNA. The multivariate ANOVA supported this observation: P-regime explained $32.7 \%$

276 of the variation in the dataset, compared to $9.5 \%$ by temperature, and $2.8 \%$ by the interaction

277 between P-regime and temperature $(p<0.05)$. Species differences accounted for $28 \%$. Both

278 specific growth rate and APA correlated strongly with the ordination ( $R^{2}$ for growth rate $=0.55$,

$279 R^{2}$ for $\mathrm{APA}=0.41$; both $p<0.01$ ). The passive variables are plotted as dashed arrows in fig. 1 ,

280 and each dashed arrow points in the direction to which the linear change in the variable is the

281 fastest.

282 The corresponding analyses for cell quota of C, N, P, and RNA (Fig. S2 and table S2)

283 revealed the same general trends, but with a much stronger influence of species due to the large

284 difference in cell size between the three haptophytes (average peak ESD for E. huxleyii $=4.67$

$285 \mu \mathrm{m}$ [sd: $0.22 \mu \mathrm{m}$ ]; C. rotalis: $4.0 \mu \mathrm{m}$ [sd: $0.1 \mu \mathrm{m}$ ] P. polylepis: $8.49 \mu \mathrm{m}$ [sd: $0.55 \mu \mathrm{m}]$ ).

286

287 Specific effects of P-regime

288 For elemental and RNA content (fig. 2 A-C, table 2), we found that cell volume-specific

289 concentrations of $\mathrm{P}$ and RNA were lower under P-limitation for all species at both temperatures.

290 The relative differences in $\mathrm{P}$ concentration between $+\mathrm{P}$ and $-\mathrm{P}$ was a factor 5.2 at $13^{\circ} \mathrm{C}$ and 5 at

$29119^{\circ} \mathrm{C}$ for E. huxleyi; 1.7 at $13^{\circ} \mathrm{C}$ and 6.3 at $19^{\circ}$ for C. rotalis; and 1.3 at $13^{\circ} \mathrm{C}$ and 1.8 at $19^{\circ} \mathrm{C}$ for

292 P. polylepis. For C and N, the effect of P-regime was less consistent, but generally, the

293 concentrations increased or were unaffected by P-regime (fig. 2, table 2). Due to the strong

294 correlation between cell-volume specific concentrations of $\mathrm{C}$ and $\mathrm{N}(r=0.96$; all data pooled),

295 C:N was not significantly affected by P-regime nor temperature (data not shown). For

296 comparison, the correlations between $\mathrm{C}$ and $\mathrm{P}$, and $\mathrm{N}$ and $\mathrm{P}$ were 0.92 and 0.85 , respectively.

297 Cell quotas of C, N, P, and RNA were generally also higher in cultures growing at $+\mathrm{P}$.

298 However, for cell quotas the effect of P-regime was weaker and in more cases non-significant

299 compared to the cell-volume specific concentrations C, N, P and RNA (Fig. S3 \& Table S3).

300 This can likely be explained by the overall trend of reduced cell size at +P (Fig. S4, table S4).

301

302 Specific effects of temperature

303 We found significant temperature effects on cell volume-specific concentrations of C, N, P, and

304 RNA, but the effect differed between species, P-regime, and element (fig. 2; $p$-values and

305 coefficient estimates are found in table 2). For all cultures growing at $+\mathrm{P}$, cell volume-specific $\mathrm{C}$, 
$306 \mathrm{~N}$, and $\mathrm{P}$ increased significantly with temperature. RNA increased with temperature at $+\mathrm{P}$ two 307 out of three species. Under P-limitation, we did not detect any consistent trend in elemental 308 content or RNA with temperature: $\mathrm{C}$ and $\mathrm{N}$ increased with temperature in two of three species,

309

310

311

312

313

315

316 while P and RNA decreased or did not change with temperature in two of three species.

Cell quota of C, N, P, and RNA typically responded less to temperature than the cell volume-specific concentrations, although the direction of the response in most cases was similar (Fig. S3 \& table S3). The weaker signal of temperature on cell quota is likely linked to the general decrease in cell size with temperature (Fig S4, table S4).

The effect of temperature on $\mathrm{C}: \mathrm{P}$ and $\mathrm{N}: \mathrm{P}$ ratios was either negative or non-significant (fig. 2 D-F, table 2): For C:P, the only significant decrease with temperature was in the $+\mathrm{P}$ culture of $C$. rotalis. N:P, on the other hand, decreased significantly with temperature under both P-regimes for C. rotalis and P. polylepis. In E. huxleyii, N:P tended to increase with temperature under P-limitation and decrease under $+\mathrm{P}$, but none of the trends were significant. For all species, $\mathrm{C}: \mathrm{P}$ ratios were well above Redfield proportions $(\mathrm{C}: \mathrm{P}=106)$ under both P-regimes. N:P ratios were above Redfield ( $\mathrm{N}: \mathrm{P}=16)$ for P-limited cultures, but below or close to Redfield when growing under nutrient replete conditions (fig. 2 D-F).

\section{Growth rate, $R N A$, and $P$}

Since RNA content was consistently higher for populations growing at $+\mathrm{P}$, RNA content was also positively correlated with growth rate (fig. 3a; all species pooled). Further, high P content coincided with high RNA content (fig. 3b; all species pooled). In both these relationships there was a grouping of the P-limited treatments, which had low growth rate, RNA, and P content, and the $+\mathrm{P}$ treatments, which had high growth rate, RNA, and P content. Also, species grouped together to some extent. Due to the grouped structure of the data, we did not fit any statistical model and only present graphical relationships in fig. 3.

The fraction of total cellular P accounted for by RNA-P (i.e., moles of ribonucleotide monophosphate per moles of total cellular P) in the three species ranged from 4-66 \% and was significantly related to temperature ( $p<0.001)$, P-regime $(p=0.025)$, and species $(p<0.001$; fig. 4). In E. huxleyii and C. rotalis, the fraction was consistently higher at low temperature, especially at $+\mathrm{P}$, but this was not seen in $P$. polylepis. The effect of P-regime on the fraction of $\mathrm{P}$ in RNA was less consistent and varied with species and temperature. 


\section{Discussion}

339 This study revealed significant and consistent effects of P-regime and temperature on elemental 340 content and total RNA in three haptophytes. The main gradient in cell volume-specific

341 concentrations of $\mathrm{C}, \mathrm{N}, \mathrm{P}$, and RNA was largely related to P-regime and the resulting differences

342 in growth rates and degree of P-limitation, the latter being independently confirmed by the

343 striking differences in APA. For all species and temperatures, we observed lower cell volume-

344 specific concentrations of P (and RNA) in the P-limited cultures compared to the exponentially

345 growing nutrient replete cultures, which is consistent with classical Droop kinetics (Droop 1974).

346 Also, the concentrations of the non-limiting elements $\mathrm{C}$ and $\mathrm{N}$ were lower in most of the P-

347 limited cultures, most notably at high temperature. Cell volume-specific concentrations of $\mathrm{C}$ and

$348 \mathrm{~N}$ were reduced less than $\mathrm{P}$ when comparing $+\mathrm{P}$ and $\mathrm{P}$-limitation, which led to consistently

349 higher N:P and C:P ratios in the P-limited cultures. That we observed no significant effects of

350 neither P-regime nor temperature on the $\mathrm{C}: \mathrm{N}$ ratio fits well with the general pattern for $\mathrm{C}: \mathrm{N}$

351 ratios in phytoplankton cultures, which is reported to remain relatively constant unless $\mathrm{N}$ is

352 limiting (Geider and La Roche 2002).

353 Temperature influenced elemental and RNA content, but the responses partly contradicted

354 our initial hypothesis, namely that low temperature should increase elemental content and RNA

355 due to a higher allocation to nutrient rich macromolecules to compensate for reduced specific

356 reaction rates at low temperature (Rhee and Gotham 1981, Woods et al. 2003, Reich and

357 Oleksyn 2004, Toseland et al. 2013, Yvon-Durocher et al. 2015). Instead, we found lower cell

358 volume-specific concentrations of $\mathrm{P}, \mathrm{N}$, and C (and RNA in two of three species) at low

359 temperature in the $+\mathrm{P}$ cultures. In the P-limited cultures, however, there was a tendency for a

360 negative or a non-significant effect of temperature on $\mathrm{P}$ and RNA (but also $\mathrm{N}$ and $\mathrm{C}$ in some

361 cases). This pattern was quite consistent in E. huxleyi and C. rotalis, but not in P. polylepis. A

362 corresponding, positive effect of temperature on $\mathrm{N}$ and $\mathrm{P}$ content under nutrient replete

363 conditions, but a negative effect under P-limitation (RNA decreased with temperature in both P-

364 regimes), was also observed a similarly designed experiment with the freshwater chlorophyte

365 Chlamydomonas reinhardtii (Hessen et al. 2017).

366 The tendency for opposite effects of temperature on elemental content and RNA in nutrient

367 replete and P-limited cultures is quite striking, and could be related to differences in uptake and 
368 storage strategies of $\mathrm{P}$ in the two growth regimes. Under P-limitation, cells cannot store extra $\mathrm{P}$, 369 and must allocate the available $\mathrm{P}$ to essential, non-storage macromolecules that are required to 370 sustain growth, e.grRNA (Sterner and Elser 2002). Hence, any changes in cellular P with 371 temperature under P-limitation should reflect a change in $\mathrm{P}$ allocated to these essential, non372 storage fractions of biomass. It is the allocation to rRNA that may be expected to change 373 according to the translation efficiency hypothesis, which specifically states that cells should 374 invest more in rRNA (and thus require more P) at low temperature. In fact, our observed elevated 375 RNA at low temperature in two of three species under P-limitation is in support of this, as are the 376 results from a corresponding experiment with C. reinhardtii (Hessen et al. 2017). Under nutrient 377 replete conditions, however, cells may take up and store $\mathrm{P}$ in excess e.g as polyphosphates 378 (Powell et al. 2009), which may overshadow any responses in the non-storage fraction of P. If, 379 for example, the uptake rate of an element increases with temperature (more than the specific 380 growth rate), higher temperature will lead to higher total cellular nutrient content even though the fraction of nutrient in the non-storage part of biomass has an opposite response to temperature. In E. huxleyi and C. rotalis (but not in P. polylepis) the fraction of total cellular $\mathrm{P}$ bound to RNA was higher at low temperature in both P-regimes. Under P-limitation, the changing fraction was due to a slightly more negative temperature response in RNA than in P. At $+\mathrm{P}$, however, total cellular $\mathrm{P}$ increased more than RNA when moving from $13^{\circ} \mathrm{C}$ to $19^{\circ} \mathrm{C}$. This points to an increased fraction of storage $\mathrm{P}$ at high temperature, perhaps due to more efficient uptake kinetics, which again lead to lower RNA:P.

The responses of cellular P and RNA to temperature in the P-limited cultures may also be related to differences in relative growth rate (RGR). The P-limited cultures of a given species were grown using the same semi-continuous dilution rate, which led to the same quasi steady state growth rate $(\mu)$ at both $13^{\circ} \mathrm{C}$ and $19^{\circ} \mathrm{C}$. Since the maximum growth rate $\left(\mu_{\max }\right)$ varied with 392 temperature, the cultures also experienced differences in the RGR $\left(\mu: \mu_{\max }\right)$. Given that the 393 maximum growth rate increased with temperature, the P-limited cultures at $19^{\circ} \mathrm{C}$ experienced a 394 lower RGR and were presumably more strongly P-limited than those growing at $13^{\circ} \mathrm{C}$. This 395 would further be expected to result in lower P and RNA content (following Droop kinetics), 396 which we observed to some extent in E. huxleyi and C. rotalis. In P. polylepis, we observed that 397 cellular P and RNA clearly increased with temperature also under P-limitation. Interestingly, the 
398 maximum growth rate of $P$. polylepis was lower at $19^{\circ} \mathrm{C}$ than at $13^{\circ} \mathrm{C}$, meaning that its $\mathrm{RGR}$ was 399 higher at $19^{\circ} \mathrm{C}$.

400 We hypothesized that high temperature would be associated with high N:P ratio, but our 401 experimental results did not support this. N:P in fact decreased with temperature in most cases, 402 except for in P-limited E. huxleyi. Our results thus run contrary to a recent meta-analysis of 14 403 experimental datasets with N:P vs. temperature from phytoplankton cultures (Yvon-Durocher et 404 al. 2015). Here, the average response of N:P to temperature was positive within species, yet with 405 large differences in effect between species and experimental units (Yvon-Durocher et al. 2015; 406 Supporting figure S7). In a recent study of six strains of Prochlorococcus cyanobacteria, 407 temperature had a weakly significant positive effect on $\mathrm{N}: \mathrm{P}$ and $\mathrm{C}: \mathrm{P}$, but the ratios decreased 408 again as temperature surpassed the optimum temperature for growth (Martiny et al. 2016). 409 Adding the results from our study to these data, it seems evident that species-specific effects, and 410 likely also effects of growth regime (exponential vs. nutrient limited) and type of nutrient 411 limitation, are important in determining the response of N:P to temperature.

412 Due to differences in cell size between treatments, we focused on cell volume-specific 413 concentrations when addressing the effects of temperature and P-regime on elemental content 414 and RNA. Comparing the responses of cell volume-specific concentrations and cell quota, we 415 generally found weaker effects of both P-regime and temperature on the cell quota. This can 416 likely be explained by the fact that cells were smaller at high temperature and $+\mathrm{P}$, the two types 417 of treatment that generally also were associated with higher cell volume-specific concentrations. 418 Hence, cells became smaller, but also more nutrient-dense at high temperature and $+\mathrm{P}$. Recent studies suggest that much of the effect of temperature on cell size may in fact be caused by 420 increased nutrient limitation both within and between species (Peter and Sommer 2013, Marañón 421 2014). Nutrient availability dominates over temperature as a predictor for the size structure of 422 phytoplankton communities in the ocean, with small species dominating in areas of low nutrient 423 availability (Marañón et al. 2012). Our results on cell size indicated that temperature was the 424 most important variable, temperature and does not support nutrient limitation as an important 425 driver for intraspecific changes in the cell size of these haptophytes. In fact, if there was an effect 426 of P-regime, cells were smaller at $+\mathrm{P}$.

427 Any changes in the stoichiometry and size structure of natural phytoplankton 428 communities with temperature will, to a large extent, be driven by shifts in species composition 
429 (Martiny et al. 2013; Maranõn 2012). To what degree intraspecific responses to temperature and 430 nutrient limitation will be important is still an open question, but the results from this study 431 indicate that the responses to temperature likely will depend on whether nutrients are limiting or 432 in surplus. Hence, increasing temperature will likely affect phytoplankton in high latitude and 433 nutrient rich waters differently from that of communities at low latitude and nutrient limited 434 regions.

435

436

437

438

439

440 
441 Table 1: Specific growth rates ( $\mu$; per day) in the different experimental combinations of P-

442 regime and temperature. The standard deviation of the three replicates is given in parenthesis.

443 Regardless of species, cultures grown at $+\mathrm{P}$ always had significantly higher $\mu$ than those grown

444 at $-\mathrm{P}(p<0.001)$. A significant $(p<0.05)$ temperature-effect within a given P-regime is marked 445 with an asterisk.

446

\begin{tabular}{|c|c|c|c|c|c|c|}
\hline & \multicolumn{2}{|c|}{ E. huxleyi } & \multicolumn{2}{c|}{ P. polylepis } & \multicolumn{2}{c|}{ C. rotalis } \\
\hline & $13^{\circ} \mathrm{C}$ & $19^{\circ} \mathrm{C}$ & $13^{\circ} \mathrm{C}$ & $19^{\circ} \mathrm{C}$ & $13^{\circ} \mathrm{C}$ & $19^{\circ} \mathrm{C}$ \\
\hline $\mathrm{P}+$ & 0.855 & 1.045 & 0.59 & $0.44(0.018)$ & $0.605(0.102)$ & $0.672(0.015)^{*}$ \\
& $(0.032)$ & $(0.016)^{*}$ & $(0.061)$ & & & \\
\hline $\mathrm{P}-$ & $0.36(0.021)$ & $0.337(0.011)$ & 0.186 & 0.229 & $0.407(0.032)$ & $0.306(0.009)$ \\
& & & $(0.015)$ & $(0.042)$ & & \\
\hline
\end{tabular}

447

448

449

450

451

452

453

454

455

456

457

458

459

460

461

462

463

464

465

466 
467 Table 2: Estimates and $p$-values from linear models on the form $\log _{10}(\mathrm{y})=\beta_{0}+\beta_{1} \times \mathrm{P}$-regime + $468 \beta_{2} \times$ temperature $+\beta_{3} \times \mathrm{P}$-regime : temperature, where y is either $\mathrm{C}, \mathrm{N}, \mathrm{P}, \mathrm{RNA}, \mathrm{C}: \mathrm{P}$, or $\mathrm{N}: \mathrm{P}$. P469 regime and temperature are both represented as factor variables with $-\mathrm{P}$ and $13^{\circ} \mathrm{C}$ as reference 470 levels, respectively. Hence, $\beta_{1}$ is the estimated difference (on $\log _{10}$ scale) in y between $+\mathrm{P}$ and $-\mathrm{P}$ 471 cultures growing at $13^{\circ} \mathrm{C}$, and $\beta_{2}$ the difference between $19^{\circ} \mathrm{C}$ and $13^{\circ} \mathrm{C}$ for cultures grown at $-\mathrm{P}$. 472 The interaction term $\beta_{3}$ represents the difference in temperature effect between $+\mathrm{P}$ and $-\mathrm{P}$ 473 cultures. The last column shows the $R^{2}$ of the most adequate model, with the fraction explained 474 by each significant term (P-regime, temperature, and the interaction between them) in 475 parenthesis. $\mathrm{n}=12$ in all models. Coding of $p$-values: $* * *<0.0001, * *<0.001, *<0.05$.

476

477

\begin{tabular}{|c|c|c|c|c|c|}
\hline & $\beta_{0}($ Intercept $)$ & $\beta_{1}(\mathrm{P}$-regime $)$ & $\beta_{2}$ (Temperature) & $\begin{array}{l}\beta_{3} \\
\text { (P-regime } \\
: \text { Temp) }\end{array}$ & $\begin{array}{l}R^{2} \text { (percentage } \\
\text { explained by each } \\
\text { term) }\end{array}$ \\
\hline \multicolumn{6}{|l|}{ E.huxleyi } \\
\hline $\mathrm{C}$ & $1.19 * * *$ & $0.3 * *$ & 0.06 (NS) & $0.176 *$ & $0.95(79,11,4)$ \\
\hline $\mathrm{N}$ & $0.13 *$ & $0.289 * *$ & $0.167^{*}$ & NS & $0.81(61,20,-)$ \\
\hline $\mathrm{P}$ & $-1.31 * * *$ & $0.637 * * *$ & 0.047 (NS) & $0.246^{*}$ & $0.97(90,4.5,2.4)$ \\
\hline RNA & $-2.26 * * *$ & $0.684 * * *$ & NS & NS & $0.88(88,-,-)$ \\
\hline$C: P$ & $2.51 * * *$ & $-0.37 * * *$ & NS & NS & $0.91(91,-,-)$ \\
\hline $\mathrm{N}: \mathrm{P}$ & $1.5^{* * *}$ & $-0.47 * * *$ & NS & NS & $0.86(86,-,-)$ \\
\hline \multicolumn{6}{|l|}{ C. rotalis } \\
\hline $\mathrm{C}$ & $1.3^{* * *}$ & $0.061(\mathrm{NS})$ & $-0.123^{*}$ & $0.395 * * *$ & $0.95(57,5,33)$ \\
\hline $\mathrm{N}$ & $0.261 * * *$ & -0.00006 & $-0.59 *$ & $0.45^{* * *}$ & $0.96(46,4,46)$ \\
\hline $\mathrm{P}$ & $-1.21 * * *$ & (NS) & -0.099 (NS) & $0.54 * * *$ & $0.98(70,9,20)$ \\
\hline RNA & $-1.96^{* * *}$ & $0.24 * *$ & $-0.26 * * *$ & $0.41 * *$ & $0.98(91,0.4,7)$ \\
\hline $\mathrm{C}: \mathrm{P}$ & $2.51 * * *$ & $0.56^{* * *}$ & $-0.024(\mathrm{NS})$ & $-0.146^{*}$ & $0.96(79,11,6)$ \\
\hline $\mathrm{N}: \mathrm{P}$ & $1.5 * * *$ & $\begin{array}{l}-0.18 * * \\
-0.29 * * *\end{array}$ & $-0.10^{*}$ & NS & $0.92(81,11,-)$ \\
\hline \multicolumn{6}{|l|}{ P. polylepis } \\
\hline $\mathrm{C}$ & $0.98 * * *$ & NS & $0.26^{*}$ & NS & $0.77(-, 77,-)$ \\
\hline $\mathrm{N}$ & $-0.87 * * *$ & NS & $0.27^{*}$ & NS & $0.53(-, 53,-)$ \\
\hline $\mathrm{P}$ & $-1.43 * * *$ & $0.18^{*}$ & $0.35^{* *}$ & NS & $0.82(17,65,-)$ \\
\hline
\end{tabular}




\begin{tabular}{|l|l|l|l|l|l|}
\hline RNA & $-1.96^{* * *}$ & $0.298^{*}$ & $0.334^{*}$ & NS & $0.80(36,45,-)$ \\
C:P & $2.37 * * *$ & $-0.154^{* *}$ & NS & NS & $0.77(77,-,-)$ \\
N:P & $1.33^{* * *}$ & $-0.145^{*}$ & $-0.087^{*}$ & NS & $0.68(50,18,-)$ \\
\hline
\end{tabular}

478

479

480

481

482

483

484

485

486

487

488

489

490

491

492

493

494

495

496 


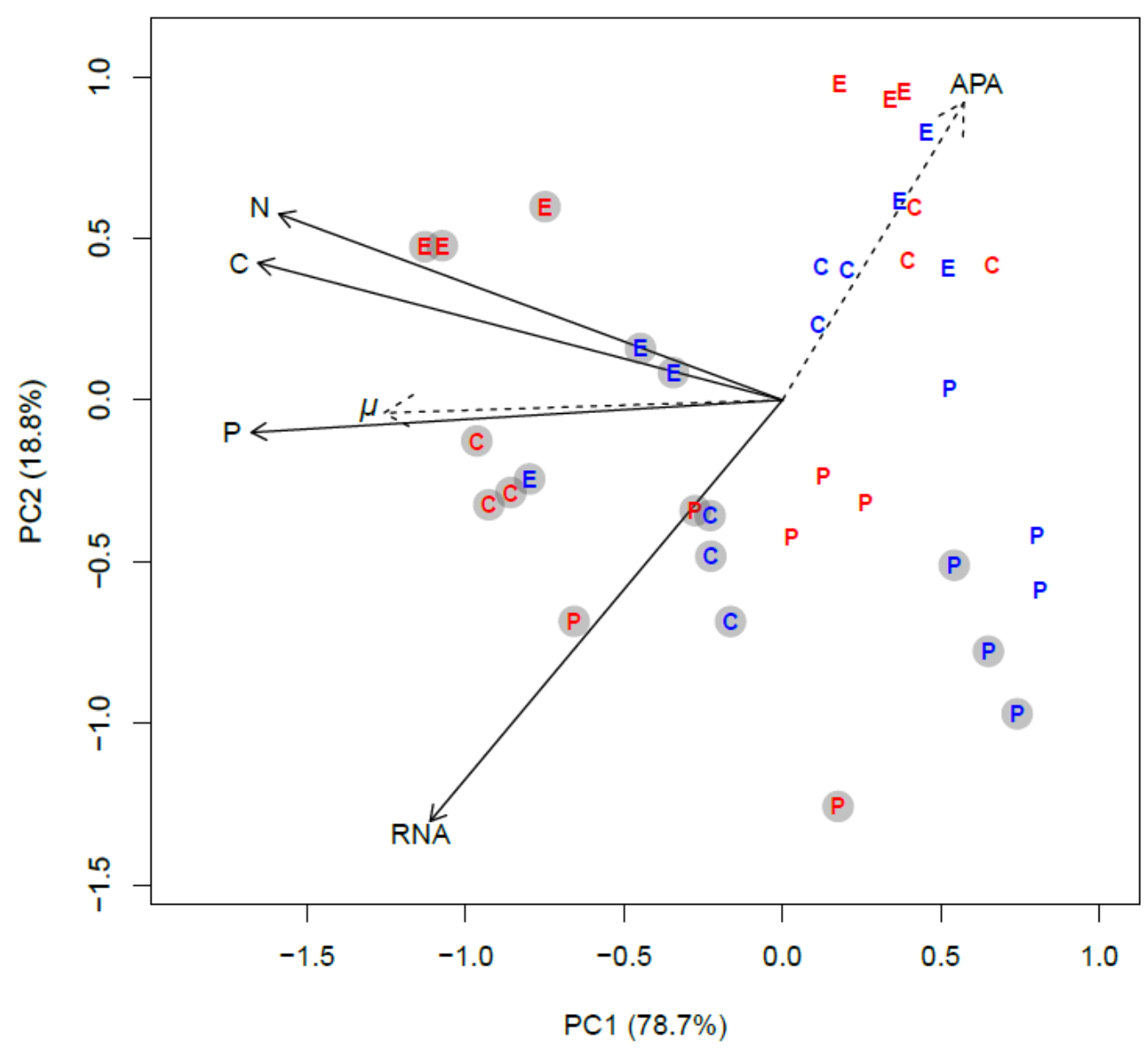

$\mathrm{PC} 1(78.7 \%)$

Figure 1: PCA plot based on log-transformed and standardized cell volume-specific concentrations of $\mathrm{C}, \mathrm{N}, \mathrm{P}$, and RNA in the 36 experimental units. Due to the factorial design with three species, two temperatures, and two P-regimes, we obtained 12 unique experimental combinations which are represented in the diagram as follows: The letters $\mathrm{E}, \mathrm{P}$, and $\mathrm{C}$ represents the species Emiliania huxleyi, Prymnesium polylepis, and Chrysochromulina rotalis; the red and blue color represents $19^{\circ} \mathrm{C}$ and $13^{\circ} \mathrm{C}$, respectively; and the grey circles represent the $+\mathrm{P}$ cultures. $\mathrm{PC}$ axis 1 accounted for $78 \%$ of the variation in the dataset, while PC axis 2 accounted for $18.8 \%$. Specific growth rate $\left(\mu\right.$; day $\left.{ }^{-1}\right)$ and alkaline phosphatase activity (APA) were included as passive variables in the PCA plot (they did not influence the ordination, but were fitted to the ordination afterwards; see methods) and plotted as dotted arrows. Each arrow points in the direction to which the linear change in the variable is the fastest. 


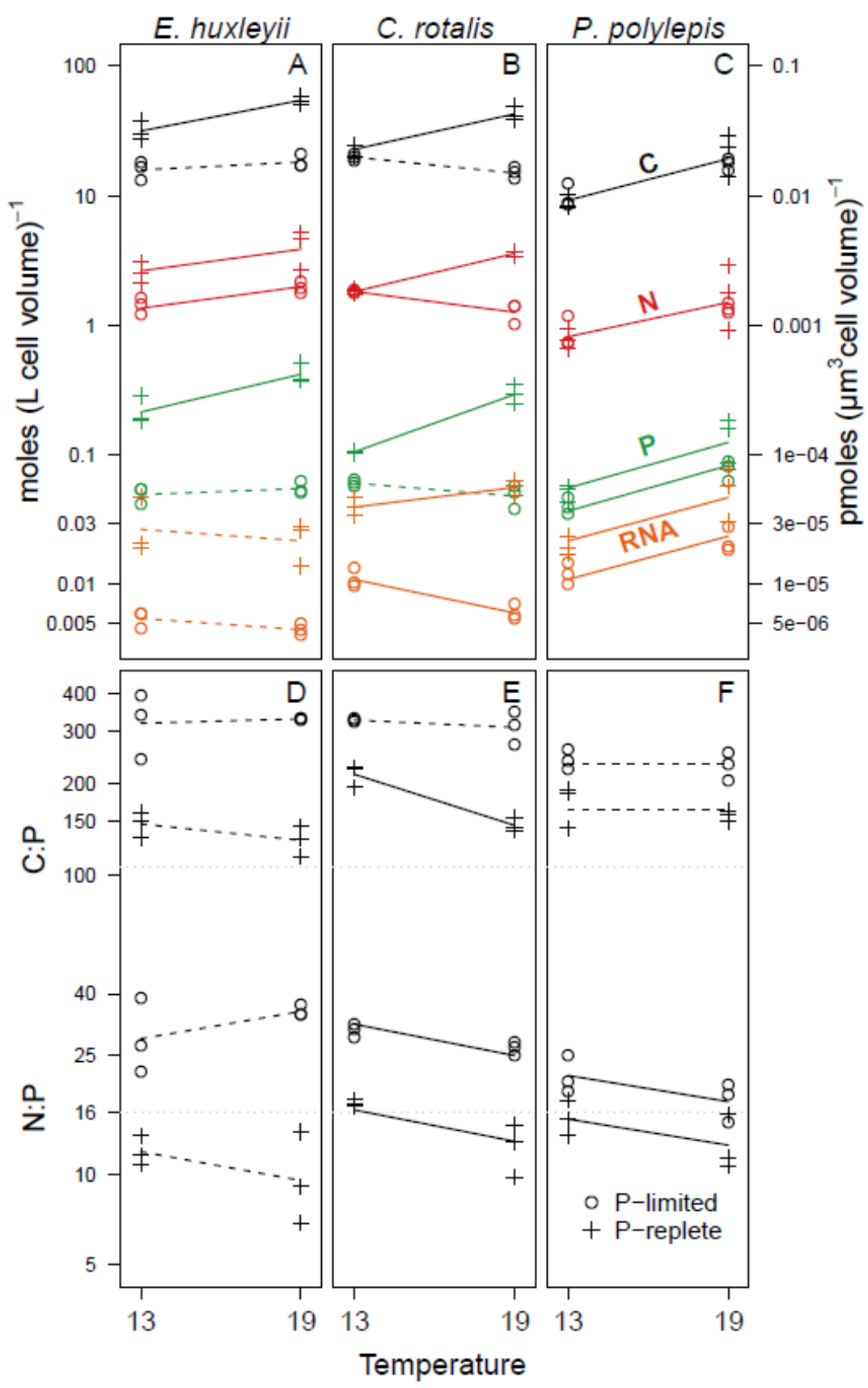

511

Figure 2: Responses of C, N, P, RNA, C:P and N:P to temperature and P-regime within species. $\mathrm{C}, \mathrm{N}, \mathrm{P}$, and RNA are expressed as moles per liter of cell volume (and pmoles per $\mu \mathrm{m}^{3}$ cell volume; right $\mathrm{y}$-axis). Ratios are atomic. The data are plotted on log-scale. Dots represent Plimited cultures $(-\mathrm{P})$, pluses $\mathrm{P}$-replete cultures $(+\mathrm{P})$. Solid lines are drawn if the difference between temperatures was significantly different from zero within a given P-regime (see table 2 for coefficient estimates and $p$-values). Dotted lines indicate non-significant trends. If two lines are drawn for an element or a ratio, there was a significant difference between P-regimes for at least one of the two temperatures. If only one line is drawn (as for $\mathrm{N}$ in P. polylepis), no P-effect was present. Grey dotted lines show the Redfield C:P and N:P ratios. 

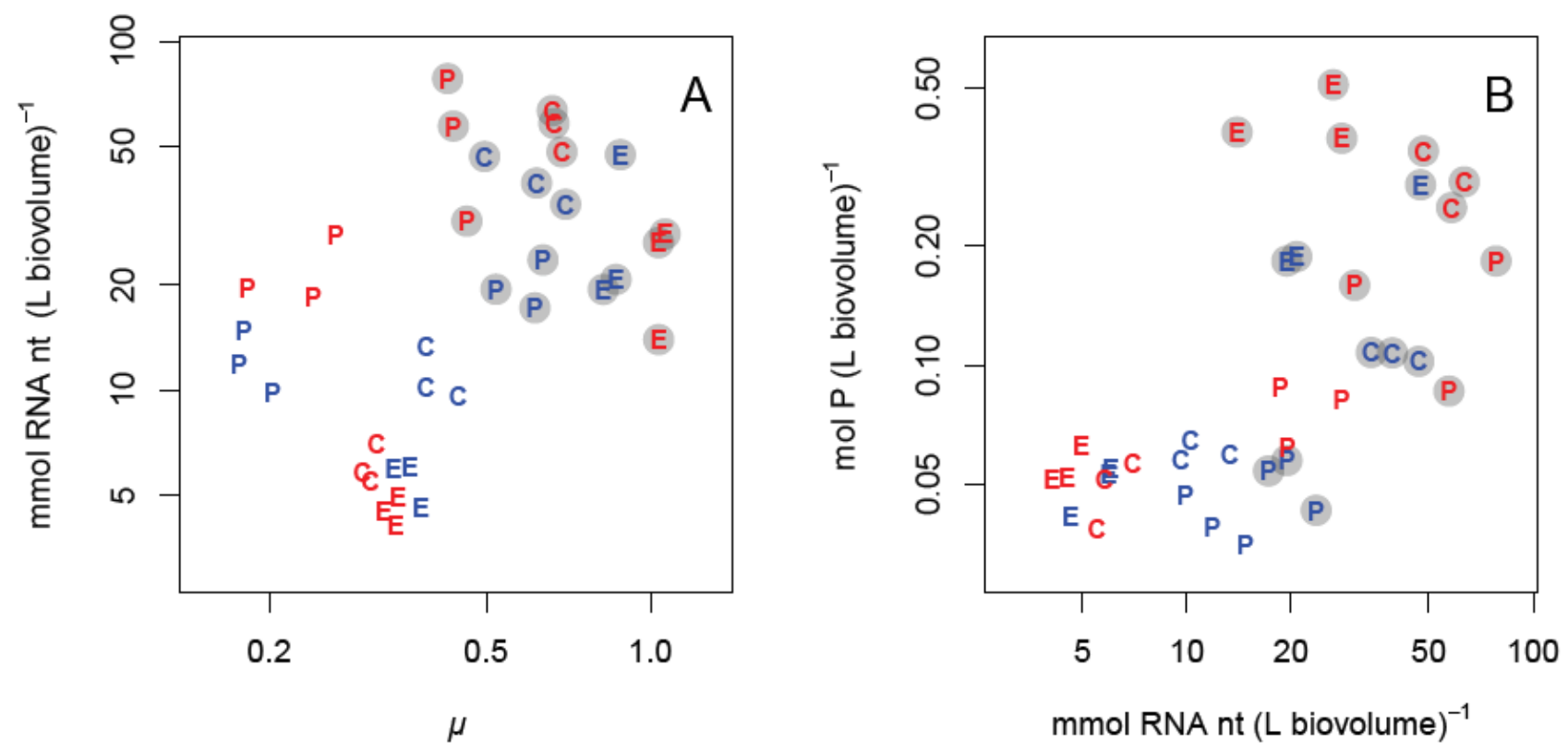

Figure 3: A) Cell volume-specific concentration of RNA (mmol RNA nucleotides (nt) per L biovolume) as a function of specific growth rate $(\mu)$. B) Cell volume-specific concentration of $\mathrm{P}$ as a function of RNA. Note log-transformed axes; dot symbols are as in fig. 1.

528

529

530

531

532

533

534

535

536

537

538

539

540

541

542

543

544

545

546

547

548

549

550

551

552 


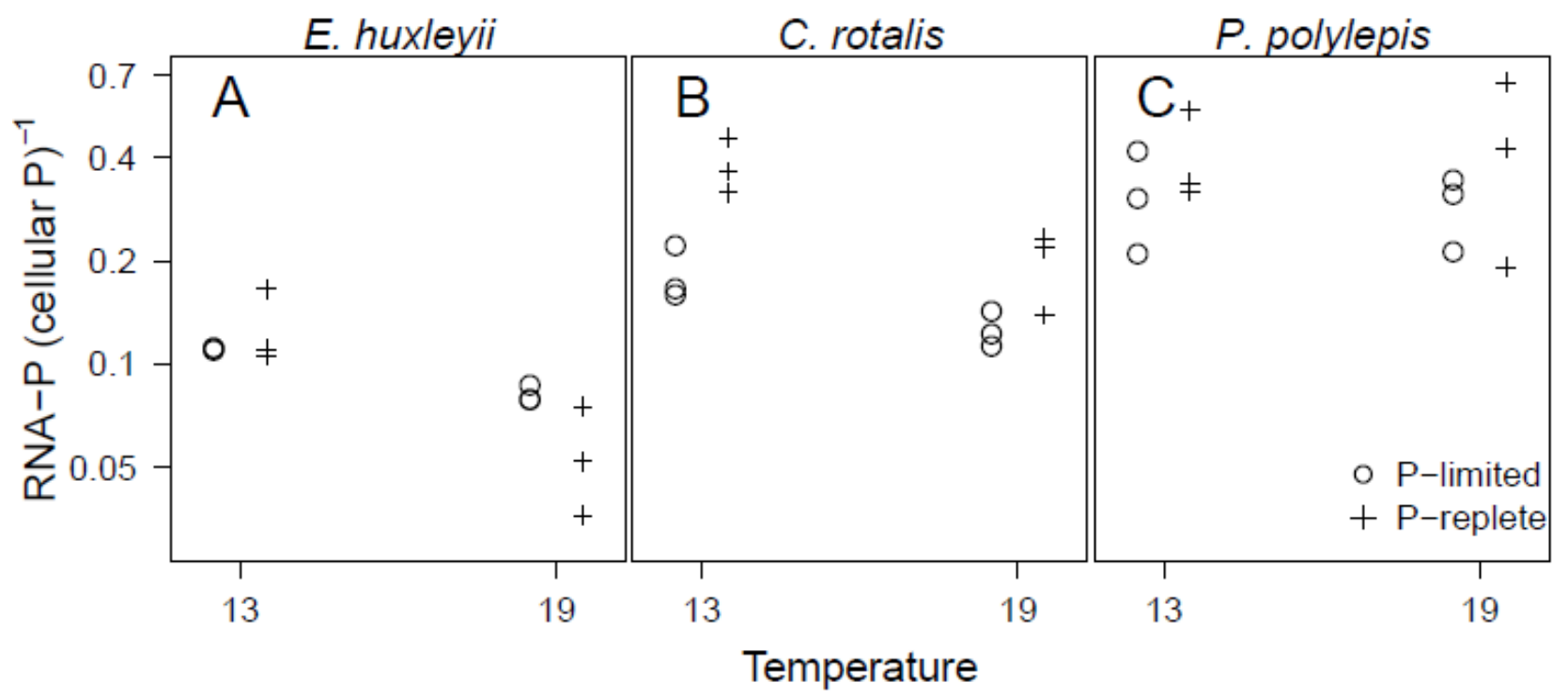

555

561

562

563

564

565

566

567

568

Figure 4: The fraction of $\mathrm{P}$ in RNA (i.e., moles of $\mathrm{P}$ bound in RNA : moles of total cellular P) plotted as a function of temperature and P-regime for each species. Dots represent P-limited cultures $(-\mathrm{P})$, pluses represent P-replete cultures $(+\mathrm{P})$. Note the log-scale on the $y$-axis. 
569 Arrigo, K. R. 2005. Marine microorganisms and global nutrient cycles. Nature 437:349-355.

570 Arrigo, K. R., D. H. Robinson, D. L. Worthen, R. B. Dunbar, G. R. DiTulluo, M. VanWoert, and 571 M. P. Lizotte. 1999. Phytoplankton community structure and the drawdown of nutrients and $572 \quad$ CO2 in the Southern Ocean. Science 283:365-367.

573

574

575

576

577

578

579

580

581

582

583

584

585

586

587

588

589

590

591

592

593

594

595

Atkinson, D., B. J. Ciotti, and D. J. S. Montagnes. 2003. Protists decrease in size linearly with temperature: ca. $2.5 \%$ C-1. Proceedings of the Royal Society of London B: Biological sciences 270:2605-11.

Behrenfeld, M. J., R. T. O’Malley, D. A. Siegel, C. R. McClain, J. L. Sarmiento, G. C. Feldman, A. J. Milligan, P. G. Falkowski, R. M. Letelier, and E. S. Boss. 2006. Climate-driven trends in contemporary ocean productivity. Nature 444:752-755.

Boyce, D. G., M. R. Lewis, and B. Worm. 2010. Global phytoplankton decline over the past century. Nature 466:591-596.

Daines, S. J., J. R. Clark, and T. M. Lenton. 2014. Multiple environmental controls on phytoplankton growth strategies determine adaptive responses of the $\mathrm{N}$ : P ratio. Ecology letters 17:414-25.

Daufresne, M., K. Lengfellner, and U. Sommer. 2009. Global warming benefits the small in aquatic ecosystems. PNAS 106:12788-12793.

Davidson, I. R. 1991. Environmental effects on algal photosynthesis: temperature. Journal of Phycology 27:2-8.

Droop, M. R. 1974. The nutrient status of algal cells in continuous culture. Journal of the Marine Biological Association of the UK 54:825-855.

Edvardsen, B., and E. Paasche. 1992. Two motile stages of Chrysochromulina polylepis (Prymnesiophyceae) - morphology, growth, and toxicity. Journal of Phycology 28:104-114.

Eppley, R. W., R. W. Holmes, and J. D. H. Strickland. 1967. Sinking rates of marine phytoplankton measured with a fluorometer. Journal of Experimental Marine Biology and Ecology:191-201.

Field, C. B., M. J. Behrenfeld, J. T. Randerson, and F. P. 1998. Primary production of the 

biosphere: Integrating terrestrial and oceanic components. Science 281:237-240.

597

598

599

600

601

602

603

604

605

606

607

608

609

610

611

612

613

614

615

616

617

618

619

620

621

622

Galbraith, E. D., and A. C. Martiny. 2015. A simple nutrient-dependence mechanism for predicting the stoichiometry of marine ecosystems. Proceedings of the National Academy of Sciences 112:8199-8204.

Gardner, J. L., A. Peters, M. R. Kearney, L. Joseph, and R. Heinsohn. 2011. Declining body size: A third universal response to warming? Trends in Ecology and Evolution 26:285-291.

Geider, R. J., and J. La Roche. 2002. Redfield revisited: variability of C:N:P in marine microalgae and its biochemical basis. European Journal of Phycology 37:1-17.

Hessen, D. O., O. T. Hafslund, T. Andersen, C. Broch, N. K. Shala, and M. W. Wojewodzic. 2017. Changes in stoichiometry, cellular RNA, and alkaline phosphatase activity of Chlamydomonas in response to temperature and nutrients. Frontiers in Microbiology 8:18.

Klausmeier, C. A., E. Litchman, T. Daufresne, and S. A. Levin. 2008. Phytoplankton stoichiometry. Ecological Research 23:479-485.

Litchman, E., P. de Tezanos Pinto, K. F. Edwards, C. A. Klausmeier, C. T. Kremer, and M. K. Thomas. 2015. Global biogeochemical impacts of phytoplankton: a trait-based perspective. Journal of Ecology 103:1384-1396.

Marañón, E. 2014. Cell size as a key determinant of phytoplankton metabolism and community structure. Annual Review of Marine Science 7:241-264.

Marañón, E., P. Cermeño, M. Latasa, and R. D. Tadonléké 2012, Temperature, resources, and phytoplankton size structure in the ocean, Limnology and Oceanography, 57: 1266-1278.

Martiny, A. C., L. Ma, C. Mouginot, J. W. Chandler, and E. R. Zinser. 2016. Interactions between thermal acclimation, growth rate, and phylogeny influence Prochlorococcus elemental stoichiometry. PloS ONE 11:e0168291.

Martiny, A. C., C. T. A. Pham, F. W. Primeau, J. A. Vrugt, J. K. Moore, S. A. Levin, and M. W. Lomas. 2013. Strong latitudinal patterns in the elemental ratios of marine plankton and organic matter. Nature Geoscience 6:279-283. 
623

624

625

626

627

628

629

630

631

632

633

634

635

636

637

638

639

640

641

642

643

644

645

646

647

648

649

Morán, X. A. G., Á. López-Urrutia, A. Calvo-Díaz, and W. K. W. Li. 2010. Increasing importance of small phytoplankton in a warmer ocean. Global Change Biology 16:11371144.

Oksanen, J., F. G. Blanchet, M. Friendly, R. Kindt, P. Legendre, D. McGlinn, P. R. Minchin, R. B. O'Hara, G. L. Simpson, P. Solymos, M. H. H. Stevens, E. Szoecs, and H. Wagner. 2017. vegan: Community Ecology Package. R package version 2.4-2.

Peñuelas, J., B. Poulter, J. Sardans, P. Ciais, M. van der Velde, L. Bopp, O. Boucher, Y. Godderis, P. Hinsinger, J. Llusia, E. Nardin, S. Vicca, M. Obersteiner, and I. A. Janssens. 2013. Human-induced nitrogen-phosphorus imbalances alter natural and managed ecosystems across the globe. Nature communications 4:1-10.

Peter, K. H., and U. Sommer. 2013. Phytoplankton cell size reduction in response to warming mediated by nutrient limitation. PLoS ONE 8:1-6.

Powell, N., A. Shilton, Y. Chisti, and S. Pratt. 2009. Towards a luxury uptake process via microalgae - Defining the polyphosphate dynamics. Water Research 43:4207-4213.

R Core Team (2016). R: A language and environment for statistical computing. R Foundation for Statistical Computing, Vienna, Austria. URL https:/www.R-project.org/.

Raven, J. A., and R. J. Geider. 1988. Temperature and algal growth. New Phytologist 110:441461.

Reich, P. B., and J. Oleksyn. 2004. Global patterns of plant leaf $\mathrm{N}$ and $\mathrm{P}$ in relation to temperature and latitude. PNAS 101:11001-11006.

Rhee, G.-Y., and I. J. Gotham. 1981. The effect of environmental factors on phytoplankton growth: Temperature and the interactions of temperature with nutrient limitation. Limnology and Oceanography 26:635-648.

Sheridan, J. A., and D. Bickford. 2011. Shrinking body size as an ecological response to climate change. Nature Climate Change 1:401-406.

Shuter, B. 1979. A model of physiological adaption in unicellular algae. Journal of Theoretical Biology 78:519-552. 
650 Sommer, U., E. Charalampous, S. Genitsaris, and M. Moustaka-Gouni. 2016. Benefits, costs and

651

652

653

654

655

656

657

658

659

660

661

662

663

664

665

666

667 taxonomic distribution of marine phytoplankton body size. Journal of Plankton Research $0: 1-15$.

Sterner, R., and J. Elser. 2002. Ecological stoichiometry: the biology of elements from molecules to the biosphere. First edition. Princeton University Press, Princeton, New Jersey.

Toseland, A., S. J. Daines, J. R. Clark, A. Kirkham, J. Strauss, C. Uhlig, T. M. Lenton, K. Valentin, G. A. Pearson, V. Moulton, and T. Mock. 2013. The impact of temperature on marine phytoplankton resource allocation and metabolism. Nature Climate Change 3:979984.

Woods, H. A., W. Makino, J. B. Cotner, S. E. Hobbie, J. F. Harrison, K. Acharya, and J. J. Elser. 2003. Temperature and the chemical composition of poikilothermic organisms. Functional Ecology 17:237-245.

Yvon-Durocher, G., M. Dossena, M. Trimmer, G. Woodward, and A. P. Allen. 2015. Temperature and the biogeography of algal stoichiometry. Global Ecology and Biogeography 24:562-570. 